\title{
The tourist corroboree in South Australia to 1911
}

\author{
Michael Parsons
}

'Corroboree', the public dance-music events staged by Aboriginal people for a settler audience, ${ }^{1}$ emerged in Australia in the nineteenth century as a cultural product jointly negotiated between two cultures. During the process of negotiation, four major framings of corroboree can be identified. Of these four, three were often only witnessed by invited guests:

- the 'peace corroboree', marking a new state of co-operative relations between Aboriginal people (representing the newly-occupied country) and the Crown (representing the new occupiers). The beginnings of this tradition in Aboriginal-settler relations can be traced to a performance organised as part of a diplomatic encounter by 'Koggie, the Native Chief of the Cow-Pasture Tribe' for Governor John Macquarie. ${ }^{2}$ Macquarie thereafter adroitly co-opted this protocol to form a part of the annual Parramatta feasts. ${ }^{3}$ In Adelaide, Governor Gawler adopted this 'peace corroboree' framing with his own annual Queen's Birthday meetings with Aboriginal people. In 1839, following the Maria massacre, the corroboree in Adelaide was specifically understood as 'calculated to restore those former peaceable relations which we hope will long subsist between us and our friendly native tribes. ${ }^{4}$

- the 'command performance' corroboree, a re-statement of the above, but now orchestrated by the new occupiers as a joint act of homage to the Crown. This

1. Ronald and Catherine Berndt observe that: " Corroboree" has passed into English as a word for all Aboriginal ceremonies and rituals and entertainments involving singing and dancing, and social effervescence generally.' (Berndt \& Berndt 1985, p. 320) As anthropologists they find 'it is too vague a term, lumping sacred and nonsacred together in an undifferentiated way, without adding anything distinctive to compensate for it.' By drawing attention to the framings of the settler-corroboree rather than categorising what was exactly being enjoyed by their audiences, this article points to how this non-differentiation came about. Thus in this article, the term 'corroboree' refers to the public events, commonly called 'corroborees' by both Aborigines and Europeans with, as I shall explain, jointly negotiated meanings.

2. Macquarie 1956, p. 9. This private performance of a corroboree was something of a diplomatic encounter, since Macquarie and Koggie were in the position of allies, following the eruption of the 'cornfield wars' that saw Koggie flee the Cow Pastures to escape attacks from inland Aboriginal groups.

3. Bruce \& Callaway 1991, pp. 78-104; Ree:ce 1967

4. South Australian Gazette, 25 May 1839, allso quoted in The Egotist, 4 June 1839. 
was itself a re-framing of the corroboree as a traditional act of welcome, but also functioned for settlers as a handy piece of ready-made uniquely local pageantry that could be included on the program for notable official visitors. Especially, standing in the shadow of the 'peace corroboree', it was an appropriate welcome to bestow on vice-regal visitors. Thus in 1856 a Mr Mclntyre, of the south-eastern district of South Australia, is reported 'riding around the country kindly collecting natives to perform a very spirited corroboree' for the Governor on an official visit. The corroboree at night, and the kangaroo hunt during the day that preceded it, were the only two activities organised. 5

- the 'gala' corroboree, the commoner's imitation of the vice-regal 'command performance' corroboree to mark significant social occasions. This drew on both the framings already described, but allowed all colonial notables to play at being Governor, while, like him, enjoying and entertaining new arrivals with a suitably novel, uniquely local, entertainment. ${ }^{6}$

The 'bleeding' of meaning from one framing to another allowed any significant colonial occasion-anything from the visit of English footballers in Rockhampton in $1898^{7}$ to the South Australian Commercial Travellers Club Charity Fancy dress Football Match ${ }^{8}$ - to add a vice-regal tang to a commoner occasion through the staging of a corroboree. Similarly, in the fourth, the commercial or touristic framing of the corroboree, the performers and promoters were able to trade on the sense of privilege and occasion established by all the co-existing framings of peace corroboree, command performance and gala corroboree, enhancing its commercial value.

It is this last framing of the corroboree which is the focus of this article. The touristic framing of the corroboree has been seen as a 'prostitution' of the 'real' corroboree, an interpretation which ignores the validity of the tourist corroboree as a new cultural artefact in its own right, ${ }^{9}$ or it has been characterised as a product of the twentieth century, ignoring the long tradition of active marketing of this artefact. ${ }^{10}$ This article will argue, using primarily South Australian sources, that the tourist corroboree, an Aboriginal-initiated and organised cultural performance, was a significant and successful attempt to

5. Register, 27 February 1856.

6. As the Melbourne-based Table Talk commented on 21 January 1887: 'Ever since British rule was established in Australia, an aboriginal "corroboree" has always been considered an amusing, if not a particularly edifying spectacle for distinguished visitors'.

7. Advertiser, 5 May 1898.

8. Register, 7 September 1911.

9. Manning Clark, for example, pictures 'the few survivors... reduced to prostituting the corroboree.... held out their skinny arms, cupped their hands and asked their white audience to "gib a penny, Mister" ' (Clark, 1968, vol. 4, pp. 222-3). Clark's sole reference for this interpretation was Noah Shreeve, miscalled by Clark 'Noel' Shreeve, whose Short History of South Australia was published in 1864. Shreeve's account, however, has no reference to skinniness, and no such quotation as 'gib a penny mister'. Rather, he tells of Aborigines explaining that they held corroborees 'for a pit of fun, the same when you got fiddle', and refusing to 'corroboree' on demand, suggesting that he return two days later for the scheduled performance (Shreeve 1864, p.36).

10. See McCannell's characterisation of the indigenous cultural tourism enterprises of 'ex-primitives' as post-modern, in McCannell 1992. Also time-specific studies, such as Altman 1988, which contextualise Aboriginal tourism as a response to latter-day political and economic opportunities. 
use symbolic goods to engage in the settler economy throughout the nineteenth and early twentieth century. ${ }^{11}$

\section{From cultivating forests to cultivating forests of symbols}

Aborigines were adroit in accommodating to the settlers' market economy, not simply occupying a subservient position in the labour market, but as sellers in a vital market for both tangibles and intangibles, for physical and symbolic goods. As access to their land and its raw materials, their economic capital, was progressively denied them, Aborigines seized upon the opportunity to market their cultural knowledge and skills, their symbolic capital, and convert it, not just into hand-outs of odd foodstuffs and token goods, but hard currency.

In Adelaide this shift is particularly well documented. Aborigines first entered the settlement economy as independent dealers in firewood, since they alone were held to have the right, conferred by their common law position as original inhabitants, to forage for wood on Crown land. ${ }^{12}$ In the first place this was for their own use. But later it was reported that that the Police and the Protector of Aborigines had been ordered to stop 'disfigurement of the trees on the Park Lands.' The conditions of the order, issued by the Governor, indicated that the Aboriginal 'spoliation' of the Park Lands' trees, had been exacerbated by the fact that in their foraging for timber, subsistence had given way to small business. The ability of Aborigines to cut Park Land trees unimpeded, had obviously attracted a non-traditional market among some settlers. Thus Aborigines were permitted now only:

to cut sufficient wood for their own fires at night, but, on no account, are they to be allowed to hawk it about for sale, and if detected in doing so, they are to be prosecuted for theft, and the parties receiving it will be charged with receiving stolen goods, knowing them to be stolen. ${ }^{13}$

The Aboriginal entrepreneurial spirit was not to be so summarily suppressed. Denied access to their natural heritage for supplying their timber business, they looked to their cultural heritage. By 1845, the year following the Governor's order, Adelaide's indigenous population, which had been cultivating their forests for trade, had begun to turn their attention to cultivating the forests of symbols for precisely the same reason.

Corroborees and firewood were interlinked in the public mind of early colonial South Australia. Thus while 'A Townsman' in 1840, writing to complain of natives cutting down trees in the Parklands for firewood made no mention of corroborees, the Reg-

11. The evolution of the Aboriginal 'tourist corroboree' tradition in South Australia and elsewhere is treated at greater length in my Ph.D thesis 'Encounters in Touriculture: indigenous cultural tourism in contested domains' submitted to Southern Cross University.

12. The common law rights of indigenous inhabitants were clearly understood at the time, as shown by McNeil 1989. Despite the attempt in South Australian settlement to declare all land as Crown land, the right of the Aborigines to the fruits of the land, including timber, was accepted.

13. South Australian Register, 24 April 1844. That the question of Aboriginal self-employment was at issue, rather than employment, was made clear in later judgements by the Police Court Magistrate. For example, in May 1850, 'Koimpa, alias Jack, an aboriginal native, was brought up for cutting timber on the Park Lands, but as he merely obeyed the instructions of a lime burner named Chamberlain, the case was dismissed' (South Australian Gazette and Mining Journal; 5 May 1850). 
ister newspaper in reply sympathised, adding 'It is impossible for our readers who do not reside in North Adelaide to form any idea of ...the nuisance of their beastly corrobories, the noise of which is so frequently carried far into the night. ${ }^{14}$ These corroborees, however unwelcome to the colonial elite who inhabited North Adelaide, quickly became a regular event; W. A. Cawthorne's diary indicates that the Aboriginal-organised 'Sunday corroboree' was a regular feature of Adelaide social life in $1845 .{ }^{15}$ That the corroborees were performed on Sundays indicates that they were intended to attract, as they did attract, settler interest; the spectators almost certainly contributed something for the performance.

Certainly by 1847 payment for the Sunday corroborees was an established practice. Complaints from the North Adelaide residents had continued through the $1840 \mathrm{~s},{ }^{16}$ and in 1847 Matthew Moorhouse, the Protector of Aborigines, was ordered by the Colonial Secretary to tell the 'Natives encamped near Adelaide' that 'this is now a Christian country' and the Sabbath must be kept holy; that they were therefore to 'abstain from making noise on Sundays'. Exasperated, Moorhouse replied that:

I have told them repeatedly not to corrobory on the Sabbath, but crowds of Europeans visit them on this day, and offer them money, and the Natives find it more profitable to listen to them than to me. Last Sunday I believe they made nearly two pounds by their performances. ${ }^{17}$

This was not merely haphazard collection of monies donated at a settler initiative. There is evidence of Aboriginal initiative in the timing, especially the regularity of the Sunday events against strong discouragement, and the publicity of these events. Thus in 1844 the Adelaide Observer reported that:

A numerous assemblage of the Aborigines of this district took place a few days since, on the Park Land, at which a large deputation was appointed from among their number, for the purpose of inviting into Town a distant tribe which has not (it is said) been regularly inducted into the Metropolis. It is a singular fact that one of the Adelaide tribe made it his business to communicate the circumstance at our Printing Office, as a matter of news, and seemed to be very anxious that it should appear in the ensuing publication. ${ }^{18}$

Visits to Adelaide from Murray Lakes and Murray River Aborigines in the 1840s anxious to see the sensational new developments in Adelaide meant that Adelaide's Kaurna people frequently found themselves hosting corroborees under Aboriginal protocol. The business opportunity offered by these events was seen very early. As corroborees were a regular outcome of such visits, it is probable that this forthcoming event was the

14. South Australian Register, 19 August 1840.

15. For example, the entry reading, without further explanation, 'went to Sunday School twice, to Chapel twice and to the Corroboree once.' W. A. Cawthorne, Litterarium diarium, 23 March 1845, A104, Mitchell Library, Sydney. Cawthorne, though, had more than a passing interest in corroboree, having published accounts in the Register in March and June 1844, taken notes on well-known Adelaide Aboriginal identities Captain Jack and King John's corroboree songs on 29 January 1844 and witnessed the Mt Barker tribe's performance on 20 May 1844.

16. For example, South Australian Gazette and Mining Journal, 6 December 1845, and 11 April 1846.

17. Letter from Moorhouse, Protector of Aborigines, to Colonial Secretary, 10 November 1847, also quoted in Hampton \& Mattingley 1988.

18. Adelaide Observer, 9 March 1844. 
'news' being advertised to readers. Thus within ten years of European settlement, Aborigines were not only organising corroborees for cash, but issuing advance 'press releases' about them as well.

On the other side of the exchange, the 'peace', 'command performance', and 'gala performance' framings of the corroboree had fostered a ready market amongst the wellto-do for corroboree paintings as either souvenirs of or substitutes for performance, fostering its position as a must-see attraction for the settler-tourists of Australia. ${ }^{19}$ This was reinforced by the ease with which the corroboree fitted European notions of the picturesque, making the corroboree an essential for artistic experience in Australia. Thus the first one-man show in South Australia, of George French Angas's watercolours of 'South Australian and New Zealand scenes, natives and artefacts', held in Adelaide on 19 June $1845,{ }^{20}$ included 'Portraits of the Aboriginal Inhabitants'. These were in fact studies of the 'Kure Dance' which Cawthorne had described in the Register the previous June. $^{21}$ When S. T. Gill took part in a Glasgow exhibition in November 1845 entitled 'South Australia As It Is', his offering was 'A Corroborie and other drawings'. ${ }^{22}$ In April 1846, John Michael Skipper, who had painted a corroboree in 1840, took a party of wellconnected city and country friends to observe a corroboree in the Park Lands. ${ }^{23}$ In November 1846, Gill's young pupil, W. A. Cawthorne, already, as noted above, a keen watcher and student of corroboree performances, was planning to enter an Amateur Artists' Exhibition with a painting of a 'Corrobberee. ${ }^{24}$ This interest in the picturesque corroboree was so marked as to draw satire, as in S. T. Gill's later painting 'The newly arrived' which depicts the gullibility of new settlers in accepting any hasty performance as their share of the 'corroboree'. But the satire is also testament to the success with which the corroboree had, through an informal joint negotiation, and despite the express discouragement of the colonial elite and the government, emerged as a form of commercial entertainment. From this point on, joint negotiation became more explicit, as a series of joint venturers undertook the staging of corroborees in South Australia.

\section{The joint venturers-artists and theatricals}

It was the artistic enthusiast of corroboree, W. A. Cawthorne, who was the first of these entrepreneurs, although he was not motivated by commercial interest. In August 1847 Cawthorne was elected onto a Provisional Committee to form a Mechanics' Institute in

19. Particularly among the well-to-do, settlement in Australia was often perceived as a temporary expedient, with return to Britain as the eventual goal; even among those who saw their settlement as permanent a touristic mentality is observable in letters home.

20. Appleyard, Fargher \& Radford 1986, p. 26.

21. Register, 15 June 1844. The article, with the byline ' $C$ ', can be found in Cawthorne's 'Rough Notes on the Manners and Customs of the Natives', reprinted in Proceedings of the Royal Geographical Society, South Australian Branch, Session 1925-6. The Register in 1885 mistakenly ascribes the earlier Register article to Angas. The Kure Dance article from the Register was quoted in full by Angas himself in his two volume work published in 1847, but credited to a friend who has frequently witnessed its performance' ie Cawthorne.

22. Appleyard, Fargher \& Radford 1986, p. 27.

23. Entry for 31 March 1846, the Diary of Miss Mary Thomas, later to become the second wife of John Michael Skipper. V1058/26A (typescript) Mortlock Library, Adelaide.

24. W. A. Cawthorne Journal on microfilm 1846-1848 B229, 1849-1859 B230 CY2141 Mitchell Library, Sydney. 
Adelaide. ${ }^{25}$ The following year at the Institute, in a public debate with the Crown Solicitor Charles Mann, he argued that nurture rather than nature was responsible for the differences between the civilised and the uncivilised. As a promotion for the debate 'several persons interested in the natives' solicited contributions for a special subscription corroboree to be held in the Park Lands on the evening of Monday 11 December 1848.26

This event displayed elements that were to be a later feature of entrepreneurial joint venture corroborees. Firstly, it was openly promoted through print media. Circulars were spread all over Adelaide giving notice of the event. ${ }^{27} \mathrm{~A}$ report was placed in the Southern Australian of a 'grand corroboree to be celebrated...near the Company's Mill. ${ }^{28}$ Secondly, the fee was collected in advance of the performance. This collection outpaced the former ad-hoc collections which, according to Moorhouse, had averaged around $£ 2$; the Monday subscription corroboree raised 'upwards of four pounds', in advance. ${ }^{29}$ (With an audience of at least a thousand persons, ${ }^{30}$ this was not impressive per capita income, although the attendance was a triumph for the organisers and a pointer to its financial potential.)

This success was in part a response to the framing of the event as part of the Mechanics Institute debate, promoted by persons of good standing in the community and as, so to speak, a recital of 'civilised' or 'civilisable' behaviour. ${ }^{31}$ Thus the press gave attention to Aboriginal professionalism, recording that they 'instructed the new comers to keep at a proper distance with a civil 'so' and a patronising 'all right' [which] seemed to be highly pleasing to the stranger whites. ${ }^{32}$ The performers wore clothes 'without being ordered to do so, but simply in deference to the white man', and the performance dealt with contact themes, including 'a brief attempt at English colloquy, in which a nonchalant aboriginal was supposed to tell a stingy settler, who denied him a mouthful of bread, that he could get plenty at the Port. ${ }^{.33}$

If this reflected a degree of stage-management by Cawthorne and his supporters, who could point to the ability to 'civilise' the uncivilised it also impacted upon the performance's perceived authenticity as a ritual tradition, a question that was to later assume greater importance. '[T]he late affair was merely at the request of three or four white men...simply a dramatic performance,' declared the Southern Australian newspaper. ${ }^{34}$ Furthermore, heralding future complaints regarding commercial corroborees, the paper commented, that 'the Corroboree of last Monday was remarkably dull', perhaps due to 'the fact of the ceremony not being spontaneous'.

25. W. A. Cawthome Joumal op. cit. 18 August 1847, Mitchell Library. Sydney.

26. Register, 13 December 1848.

27. Adelaide Times, 18 December 1848.

28. Southern Australian, 8 December 1848.

29. Register, 13 December 1848.

30. Adelaide Times, 18 December 1848; Register 13 December 1848.

31. It is interesting to note that amongst the audience 'were several natives who professed themselves too much civilised to join in a corroboree'. Register, 13 December 1848.

32. ibid.

33. ibid.

34. Southern Australian, 15 December 1848. 
The further development of the commercial corroboree in South Australia was checked by the 1850s Victorian gold rushes. The loss of the South Australian European labour force to the goldfields stimulated the rural demand for Aboriginal workers. To meet this demand the Government closed the Native school in the Park Lands and discouraged Aboriginal visitors to the city; Aboriginal economic activity was diverted to rural industry. Simultaneously, however, in newly-prosperous Victoria, the jointlynegotiated development of the corroboree led to the framing of the commercial corroboree as theatre of spectacle.

\section{The corroboree as theatre: a Victorian interlude}

In 1855 Melbourne's Queens Theatre announced their New Year's holiday surprise, a 'Corroboree' in which 'Native Blacks will give their War Dance, Hunting Songs, \&c., \&c. ${ }^{35}$ The Melbourne Age informed its readers that the attraction had 'draw[n]good houses' and that the party had performed 'several of their native customs-the war song and dance, hunting-song, \&c. much to the amusement of a crowded audience'. ${ }^{36}$ The Melbourne Argus also reported that:

The main feature...for the last two nights has been the introduction of native dances or corrobborees, performed by the aboriginal natives of this colony. The dances are characteristic...consisting for the most part of violent, muscular exertion. The 'Old Man' corrobboree, the 'Kangaroo' corrobboree, and a third dance, peculiar to the natives of this colony, are the dances selected. The house was well attended on both occasions, many new arrivals conceiving it to be a treat to witness the natural dances of the aborigines. ${ }^{37}$

Despite the success of the Queen's Theatre enagagement it was not repeated. Four years later in Ballarat, however, another attempt was made by Aborigines and producers to stage mainstream theatre corroborees. At that time, at their camp at the Swamp, Aborigines could be periodically found entertaining 'groups of well-dressed Europeans, both males and females' with corroboree performances for one shilling each. ${ }^{38}$

In May 1860, just prior to the Queen's Birthday, the corroboree performances of visiting Ararat Aborigines were apparently so well patronised that the whole group was 'invited to perform at the Royal Theatre'. Their performance 'completely astonished the audience', according to the Lamplough correspondent to the Ballarat Star:

After the first piece was over, one of them appeared at the footlights, and announced a programme of what would be exhibited before us. In his intelligence and manners he was a pattern to hundreds I have seen of Europeans attempting to address an assemblage. One of them has gone up the country for 50 more, and a grand evening's entertainment is to be given by them at the Royal. ${ }^{39}$

The framing - the literal framing-of the corroboree within the proscenium arch paralleled a tendency for settlers to perceive Aboriginal performance through their own theatrical experience, which at that time included a great emphasis on spectacular effects.

35. Argus, 3 January 1856; Argus, 4 January 1856.

36. The Age, 2 January 1856

37. Argus, 3 January 1856.

38. Argus, 13 March 1857. Reprint from The Ballaarat Times.

39. Ballarat Star, 21 May 1860, reprinted in Argus, 22 May 1860. 
In 1867 a corroboree in Ballarat was produced by a purveyor of pyrotechnic displays. It was reported that:

A curious effect was produced by the glare of the colored lights thrown upon the group as they went through their diabolic looking manoeuvres, which appared to partake very much of the scenic qualities of the celebrated opera, 'Der Frieschutz'. 40

(Der Freischutz was a popular opera at the time ${ }^{41}$, and its Wolf's Glen scene offered a convenient morphic resonance between the corroboree and European cultural experience. ${ }^{42}$ )

Many other references could be given of Europeans appreciating the tourist corroboree by comparing and contrasting it with their own dance-theatre. ${ }^{43}$ Theoretically, therefore, a potential was present for corroboree performances to develop and obtain legitimacy in the European mainstream theatrical domain, as the existing 'tourism' infrastructure of the time. ${ }^{44}$ But in practice Aboriginal performers appear to have been unable to build careers in the mainstream theatre and other sections of the non-itinerant entertainment industry in major cities. In Ballarat, as in Melbourne, there were no repeat performances even after a highly successful season of Aboriginal entertainment. Nor was there yet a significant return to the purely Aboriginal-initiated and -managed tourist corroborees. Instead, the corroboree developed in joint venture arrangements with European vested interests from outside the mainstream theatre industry. ${ }^{45}$

\section{The joint venturers-publicans and sportsmen}

If the Mechanics Institute promoters used corroboree as a concert item, as a sign of civilisation, others were at the same time promoting corroboree as a form of sports spectacle, for profit. Publicans and sporting association executives were the most prominent of these. In many cases these two roles were combined, for publicans often acted as sports officials and outdoor entertainment impresarios, since the hotel itself, as an attraction, was limited in size and scope, and was well supplemented by a crowd-pulling outdoor 'event'.

This triple linkage of hotels, sporting events and corroboree was in South Australia most strongly exemplified in the Kensington area, east of Adelaide. In September 1850 publicans there organised a spear-throwing contest with a hundred Aboriginal participants, offering 'a variety of cheap prizes for different events... to give new colo-

40. Ballarat Star, 2 April 1867. The reference to 'Der Freischutz'. Weber's romantic opera subtitled 'The Fiend of the Forest', reflects a perception of Aborigines as demonic, more clearly seen in the Ballarat Evening Post review of the same date: 'The spectacle of a number of fantastically dressed paint-streaked blackfellows cutting their capers under the light of coloured fires and to the music of clattering sticks, had a very weird effect, and produced the impression of demons at their orgies.'

41. Der Freischutz was one of the earliest operas performed in Adelaide. Adelaide theatre-goers first saw it in August 1840 when the Argyle Theatre re-staged the successful Sydney production (Adelaide Guardian, 26 October 1839). Freischutz arias were also popular as concert recital pieces. For example it was reported in 1850 in Adelaide that 'Mde Cranz gave her long promised concert-Scena from the Freischutz' (South Australian Gazette and Mining Journal, 5 May 1850). 
nists an opportunity to witness the rude methods by which the aborigines secured their daily food. Their hotels naturally did a roaring trade throughout the afternoon.' ${ }^{46}$

Given the success of events in the Park Lands commercial corroborees were the logical next step. Private Aboriginal ceremonies were still held in Kensington in 1847 'at the bend downstream in Hallett's Rivulet [from the] bootmaker's shop in Bridge Street. $^{47}$ As settlement built up this encouraged development of the commercial corroboree in the area. In 1855 the March Report of the Protector of Aborigines reported 'boisterous' corroborees being frequently held in Kensington 'encouraged thereto by liberal donations in money, and by supply of strong drink most reprehensibly furnished them. $^{48}$

The hotel-corroboree link emerged elsewhere in South Australia during the nineteenth century. Thus in 1872 the Register reported that in Kapunda 'a number of natives from the Murray were induced to perform at the Sir John Franklin Hotel.' The performance was 'well attended' and a set fee was charged the spectators. Perhaps to offset the negative associations of the linkage with the hotel's patronage, the paper noted that 'proceeds will be devoted to supplying the aboriginal players with lines and hooks for fishing'. ${ }^{49}$

Nonetheless the association of hotels with alcohol as well as with corroborees fed into the growing double exposure, in the colonial imagination, of the images of Aborigines and intoxication. (As such it was to rebound on Aboriginal performers' ability to capitalise on their break into the mainstream sports-entertainment industry in Adelaide in 1885.) The readiness of hotel-promoters to insist on Aboriginal participation in pre-arranged events occasionally exacerbated this association in the minds of missionaries and others concerned with Aborigines' welfare. Thus when, in 1860, a well-advertised corroboree performance in Kensington ${ }^{50}$ was something of a failure, the Advertiser reported that "many more "blackfellows" would have assembled, but it

42. A fascinating example of how the consonance of this opera's Wolf Glen scene with corroborees was felt by both Europeans and Aborigines was recorded by Sir Roger Therry. He recounted how, 'a gentleman, himself a native of the colony' around 1854 'took a party of Jervis Bay and Illawarra blacks to the Sydney theatre, to witness the opera of 'Der Freischutz' chiefly with the view of observing what effect the incantation-scene would have upon them. The scene in the Wolf's Glen rivetted their attention. They exhibited great excitement at the circle of skulls in the glen; the mystic casting of the seven bullets; Zamiel, the red man with the long fingers; the toads, and frogs, and other reptiles on the ground; the firing of the gun, and fall of the bird, \&c. Six or seven years afterwards this gentleman visited Jervis Bay, and 'was surprised to witness' the incorporation of several aspects of the Wolf's Glen scene into 'one of their moonlight entertainments... They painted their bodies red and various other colours to represent the characters in the opera; with boughs of trees they constructed the glen; guanas [sic], frogs and other animals were supplied by their native forests. The firing of the gun and bringing down the bird, and, in short, all the principal scenic incidents of the opera, were imitated with amusing mimicry' (Therry 1863, p. 297).

43. See, for example, Mitchell 1834, vol. 2, pp. 4-6, or Mary Thomas in 1846 (extracts from the diary of Miss Mary Thomas, V1058/26A, typescript, Mortlock Library, Adelaide).

44. Notwithstanding the fact that the theatre at this time had a somewhat doubtful reputation. In 1839 , the proposal for a subscription theatre in Adelaide, prompted the giving of assurances that it would be 'upon a scale of propriety and selectness, which will ensure it the patronage of families...to the exclusion of promiscuous and incidental support... The want of innocent recreation is strongly felt in Adelaide' (Adelaide Guardian, 26 October 1839). 
appears they had obtained alcohol and became intoxicated'. In this case the commercial corroboree had been pressed forward despite the death of a member of the group. Unabashed, the promoters announced that a 'grand corroboree is to celebrate his funeral'. ${ }^{51}$

The link with sport meant that Aborigines playing sport and Aborigines dancing 'corroborees' also became linked in the public mind as a form of theatrical spectacle. This view was reinforced by the promotors. Their marketing of Aboriginal sporting fixtures and Aboriginal corroborees virtually did not distinguish between the two, with advertising appealing to their crowd-pleasing entertainment value.

By the 1880 s it was the elder statesman of the brewing industry and noted sports patron Edwin Smith and his gadfly protege, the Football and Cricketing Association secretary John Creswell who featured prominently in assisting the staging of the most spectacular and financially successful corroborees in Adelaide. ${ }^{52}$ The South Australia Cricketing Association had the lease on the Adelaide Oval, and under Creswell's impresario management style not only organised football and cricket matches there, but also fireworks displays and moonlight concerts. Following the strong success of Aboriginal cricket as an entertainment spectacle in Victoria, it was not surprising that Creswell should become involved in similar events in South Australia. ${ }^{53}$

It was not Creswell, however, but the Aborigines of Point McLeay Mission who first proposed a match be played on the Adelaide Oval; in October 1880 the South Australia Cricketing Association first agreed to a request from John Wilkins 'on behalf of $\mathrm{Pt}$ McLeay natives asking if South Australia Cricketing Association could arrange a match against 18 of them' ${ }^{54}$ The Association agreed, but two months later Point McLeay missionary Frederick Taplin "expressed a wish that the Association would quash the Match

45. Fringe itinerant theatre was another option. Some Aborigines pursued acrobatic careers in roving vaudeville or burlesque bush shows. Some became famous as stars of touring colonial circuses, such as Ashton's trick rider Mongo Mongo and the Aboriginal contortionist Combo Combo. (St Leon 1993; Ararat and Pleasant Creek Advertiser, 20 August 1867). Con Colleano became one of the world's greatest circus tightrope acts, after performing in Australia as a 'Royal Hawaiian.' (St Leon 1993) A more recent version of this tradition may be seen in sideshow Boxing Tents, and the rodeo circuit.

46. Smith [1973], p. 50. This was by no means the earliest such event in this area: see Stephens 1889, p. 484.

47. Manning 1976, p. 12 . This area is now a recreation reserve.

48. Observer, 2 June 1855.

49. Register, 26 March 1872.

50. Register, 4 October 1860 . The advertisement appeared as a news item, under the heading 'Native Doings'.

51. Advertiser, 5 October 1860.

52. 'As a sports administrator, Creswell became a 'household name' in South Australia.' Australian Dictionary of Biography, vol. 6, p. 144. He was founder and secretary of the South Australian Football Association and secretary firstly of the Kensington and Norwood Cricket Association in 1881-83 and after, the South Australia Cricketing Association until his death in 1909. Smith was owner of the Kent Town Brewery and Mayor of Kensington and Norwood from 1867-70 and 1871-73 and Mayor of Adelaide from 1879-81 and 1886-87. He was a Member of Parliament from 1871-93.

53. It was Thomas Wentworth Wills's Aboriginal cricket team from the Western District of Victoria which famously toured England in 1867, supplementing the entertainment value of their cricket-playing with exhibitions of traditional sports. 
as he was afraid of the effect on some of the Aborigines if they got into Adelaide.' The Association decided not to proceed.$^{55}$ A further attempt in 1882 also failed. ${ }^{56}$ Creswell became Secretary the next year.

In May 1885 around one hundred Aborigines from Point McLeay Mission and Yorke Peninsula were assisted by the Government to visit Adelaide during the week of the Queen's Birthday and hold 'a tribal meeting' and perform a corroboree in the Exhibition Grounds, for a small admission charge 'for their own benefit'. ${ }^{57}$ Creswell quickly seized his opportunity. That afternoon he negotiated with them to play the first football match held between Aboriginal and non-Aboriginal teams in Adelaide and also negotiated an agreement on behalf of South Australia Cricketing Association with the Aborigines for the corroboree to be transferred from the Exhibition Grounds to the Adelaide Oval on 29 May for a half share of the proceeds. He obtained last-minute permission from the Adelaide Town Clerk for the performance, and had it advertised in a large notice in the 28 May afternoon edition of the Express and Telegraph. ${ }^{58}$

The first football match, despite its short notice, was an unqualified success. ${ }^{59}$ Due to the demand a second was held at the Adelaide Oval on Tuesday 2 June 1885, attracting a crowd of several hundred people. ${ }^{60}$ The corroboree, in contrast, on the 29 May attracted a crowd of 20,000..$^{61}$ At approximately one-sixth of Adelaide's population, it was by far the largest event ever staged on the Adelaide Oval in the nineteenth century. In fact, due to overwhelming public demand, three corroborees were held. The second was on 30 May at the Adelaide Oval, at the request and in the presence of the Governor, and the third at the Kensington Oval, on 3 June, organised by the Kensington and Norwood Cricketing Association.

The Express and Telegraph's review of the first of the three corroborees is representative:

It is many years since the residents of Adelaide have had the opportunity afforded them of witnessing a real native corroboree on anything like a large scale, and the announcement that such a novel exhibition would take place on the Adelaide Oval on Friday evening created a great deal of interest.... [But] it was a very tame affair. Those who went to witness a genuine and hearty corroboree of the olden time were grievously disappointed; but this was in a great measure due to the dreadful crush of people, larrikins and larrikinesses having it all their own way.

This was a reference to the 'rushing' of the event by the crowd who threw down the hurdles which had been erected to keep a performance space clear, and to the general noise of the crowd, which 'almost drowned out' the women's chanting. It appears from

54. South Australia Cricketing Association Minutes 11 October 1880, Mortlock Library, Adelaide.

55. South Australia Cricketing Association Minutes 8 December 1880, Mortlock Library, Adelaide.

56. South Australia Cricketing Association Minutes 5 September 1882, Morlock Library, Adelaide.

57. Register, 28 May 1885

58. Express and Telegraph, 28 May 1885, Afternoon Edition.

59. Adelaide Observer, 30 May 1885.

60. Express and Telegraph, 2 June 1885, also 3 June 1885.

61. Register 30 May 1885. The estimate appears reasonable. The same week 30,000 attended the Queens Birthday Review (Pictorial Australian, June 1885). It was also estimated that 12,000 to 15,000 were already on the ground before all the gates were thrown open before a surging crowd (Advertiser, 30 June 1885). 
the account that the performers did not complete the program due to the crowding and general confusion.

[L]arge numbers swarmed in on the 'free list', and augmented the already immense crowd...from 12,000 to 15,000 people...£200 was taken, and this sum does not nearly represent the number of persons present. The grand stand was packed to double its capacity, there was not standing room on the lawn, and the cricket ground itself was densely covered... Half of the proceeds, after deducting expenses, will be handed over to the Protector of Aborigines, who will in turn pass the money onto the blacks and the other half will go to the association. ${ }^{62}$

The South Australia Cricketing Association's net profit for the two corroborees amounted to $£ 101.7 .5$, which meant that the corroboree netted over $£ 200$ profit. $^{63}$ In comparison, the final gate-takings for South Australia Cricketing Association that year for all cricket matches were $£ 157.19 .6$, while the two English vs Australia Tests netted E84.18.9. ${ }^{64}$

The Express and Telegraph's review of 'Saturday Night's Corroboree' is worth quoting at length for the clarity with which it indicates the multiple framings of corroboree which informed the tourist corroboree. The reviewer reported that the dancers entered:

singing at the same time 'God Save the Queen'-'an expression of loyalty so unexpectedly and pleasingly displayed was duly acknowledged by the Governor and appreciated by the onlookers. Meanwhile the lubras had begun their chanting and beating on opposum skins, and a large number of torches placed in the corroboree reserve were lighted. In addition, colored lights and some fireworks were let off, so that the whole scene became exceedingly picturesque. About thirty-five blackfellows were prepared to take part in the proceedings. They were naked with the exception of a trunk, and the exposed parts of their bodies were marked in a variety of ways, but upon what principle is best known to themselves. Some were merely smeared with white, whilst others had white or red lines across the breast and back and down the legs. Anyhow as they moved about amongs the flickering lights they presented a very grotesque appearance. The first part of the programme consisted in the representation of a mob of kangaroos hopping about and stooping down as if feeding...The imitation was not all bad.

This, the first act, was repeated at various points all around the circle of spectators, so that all might have a fair chance of seeing the performance. The second act was no doubt intended to be a little satire on civilization...Most of the blacks belong to the blue-ribbon organisation and having been weaned from the 'cup' apparently desire to disseminate the principles they have embraced. There is a wealth of suggestion to temperance advocates in this long-wanted novelty, and a new mine of anecdote and illustration might be opened up and put to use. The idea of the blacks was to dramatically represent the action of 'liquoring up', and for this purpose they went down on their knees-possibly to signify that drinkers were weak-kneed-and all lifted alternately with each hand. This was repeated three times until the semi-circle had been concentrated. Then the darkies stood, went through some pantomime, and suddenly fell down, yelling and tumbling about. By this they meant to signify intoxication, but it was

62. Express and Telegraph, 30 May 1885.

63. South Australia Cricketing Association Annual Report 1884-1885.

64. ibid. 
considerably different from the conventional stage impersonation...The last part of the corroboree consisted of a native dance, supposed to be in honour of success of the kangaroo hunt. Some of the performers decorated themselves with gum leaves in the orthodox fashion, and standing in line the blacks shook their legs and assisted the lubras in their accompaniment. The last 'event' was a 'saltwater' dance by about a dozen of the Yorke's Peninsula blacks, but what it meant was not clear. Altogether the corroboree, being of a peaceable character, was not so wild or startling as might be expected... but at the same time the frequent applause showed that the spectators were satisfied with what they saw. At the conclusion the Aborigines again sang 'God Save the Queen' and the affair terminated. ${ }^{65}$

This corroboree, performed at the request of the Governor, Sir William Robinson, and during the festivities of the Queen's Birthday, was a confluence of all previous joint venture corroboree framings, of the 'peace corroboree', the 'command performance corroboree', the 'gala corroboree' and, in its various guises, the 'commercial corroboree'. Also present was the tradition of 'sports' corroborees, with South Australia Cricketing Associations promotion of the event and the concurrent inaugural 'Black Vs. White' football matches. It also presaged the 'missionary corroboree' with its temperance movement-play segment by Aboriginal Blue Ribbon Army members.

Given that up to twenty thousand people had rushed to see a corroboree on 29 May 1885, and at least another five thousand had paid to see a performance on 30 May, it was a tribute to the level of demand and client satisfaction, that on 3 June, 1800 attended a corroboree by eighty Aborigines in 'uncertain weather' at the Kensington Oval. It was reported that the dancers 'went through precisely the same manoeuvres as they did on the Adelaide Oval.' Coloured lights and fireworks lit the dance area on the lawn in front of the pavilion, with more light provided by 'bottle torches and bags saturated with tar and kerosine mounted on iron bars.' As at the Adelaide Oval, the performance concluded by Aborigines singing the first verse of the National Anthem 'for which they were loudly cheered' ${ }^{66}$

It was expected that, due to the success of the corroborees, it would be made an annual event. The Aborigines Friends Association, however, opposed the idea. Consequently in June 1886, a number of the original Point McLeay Mission group of performers led by Archie Blackmore en route to Adelaide to perform a corroboree were intercepted by police at Mt Barker. A compromise agreement was personally hammered out between them and the Protector for them to get free rail passes to seek work at Morgan instead. This was not before 60 to 70 had given 'a mild corrobboree' at Strathalbyn 'in the presence of a large gathering of residents, who were attracted by the novel proceedings ${ }^{67}$ and another corroboree in Mt Barker. ${ }^{68}$

As is detailed below, the commercial joint venture corroboree then underwent another remarkable transformation, and emerged as a missionary fundraiser. The sportsmen, however, were not deterred from the exploitation of indigenous cultural tourism. In January 1889 the South Australia Cricketing Association finalised arrange-

65. Express and Telegraph, 1 June 1885; reprinted Advertiser, 1 June 1885.

66. Observer, 6 June 1875.

67. Register, 9 June 1886.

68. Mount Barker Courier, 18 June 1886. 
ments for the Maori Football and Fireworks Show to play on the Oval for three days, which netted them a handy profit of 'about $£ 50$ to $£ 60$ '. 69

\section{The joint venturers-missionaries and friends}

Early missionaries sometimes saw as 'corroborees' Aboriginal rituals that were rarely witnessed in cities and towns. ${ }^{70}$ In November 1821, NSW missionary William Walker told a colleague 'it was of too shocking a nature too unseemly-too disgraceful to describe-were not my duty concerned, my curiosity could never prevail on my sense of delicacy, to visit a Corrobaraa. ${ }^{71}$ Missionary opposition to 'corroborees' has come to be framed in these terms by modern writers. For example, Point McLeay's founding missionary George Taplin is often quoted as declaring that

The dances of the women are very immodest and lewd...I have seen dances which were the most disgusting displays of obscene gesture possible to be imagined, and although I stood in the dark alone, and nobody knew I was there, I felt ashamed to look upon such abominations. ${ }^{72}$

But this is only half of what Taplin actually wrote. The extract actually begins:

At night, what the white men call a corrobery, but which is called by the Narrinyeri ringbalin, is the favourite amusement...in most ringbalin only the men dance; the women sit on the ground and sing. The songs are sometimes harmless, and the dance not indecent, but at other times the songs will consist of the vilest obscenity. The dances of the women are very immodest and lewd...

It is an oversimplification to suppose that missionary opposition to 'corroboree', and especially the tourist corroboree, which was far more likely to consist of Taplin's 'harmless songs', was based on prudery. For the missions, the concern was primarily social control, to restrict Aboriginal people from being able to enjoy their traditional patterns of seasonal movement and from achieving a measure of economic independence. ${ }^{73}$ A similar concern can be traced in mission reaction to Aboriginal employment in rabbit-hunting. The 1885 Yearly Report of the Aborigines Friends Association stated that rabbit hunting

69. South Australia Cricketing Association Minute Book. Mortlock Library, Adelaide. Meetings of 15 January 1889, 12 February 1889. Another engagement was finalised at the end of April that year, ibid., 30 April 1889.

70. An exception is that recorded by W. A. Cawthorne. On the Queen's Birthday in 1844, in the the Adelaide Park Lands he:

saw natives in large bodies-strode over to them-found them all straggling about comprising various tribes-Some of them were performing that curious ceremony of inaugurating young men into manhood-which is done by laying them down on their backs \& smearing their bodies all over with red ochre \& grease - \& then a female comes forward \& plucks out the hair of the pubis!!!!! The men finish the work.

This initiation ceremony was clearly not intended as general entertainment, unlike the corroborees dealt with in this article.

71. quoted in Gunson 1974, p. 73.

72. Taplin, in Woods 1879, pp. 37-8, also quoted, for example, in Berndt \& Berndt 1985, p. 381 and Bruce \& Callaway 1991. Taplin's confession that he was watching alone and in secret is suggestive of a prohibition on male viewing of this women's dance. A 1995 Royal Commission into Narrindjeri women's beliefs accepted evidence that the Narrindjeri did not possess a tradition of 'secret women's business' as allegedly there was no record of its existence. While not a definitive record, Taplin's diary is at least a possible indication of such business existing. 
affording as it does full employment for all able-bodied natives [is]a considerable hindrance in several respects...the nomadic life of the rabbit hunter together with the high wages earned and consequent extravagant and improvident habits encouraged, call up serious doubts as to any real benefits afforded by this means of livelihood. The work, however, is one that suits the Aboriginal taste. ${ }^{74}$

If rabbit-hunting suited the Aboriginal taste, corroborees did so even more. Corroborees, even more than hunting skills, were a form of cultural capital that could be readily converted into economic capital, rousing even more the hostility already shown to rabbit-hunting. But the predilection of the powerful for 'peace', 'command peformance' and 'gala' corroboree framings, ensured the social acceptability of the corroboree performance. With the continuing bestowal of a vice-regal imprimatur, it became difficult for missionaries to resist the legitimacy of demands to view corroborees.

When the Register queried, in its coverage of the first Adelaide Oval corroboree 'whether those responsible for the management of Point McLeay and Point Pierce institutions gave the sanction to this revival of a barbaric performance ${ }^{75}$ the reaction showed how bitterly this patronage of the powerful was viewed in mission circles. The Rev. Mr Cox, Chairman of the AFA, denied that any such sanction had been given by the Point McLeay committee, and averred that 'they have had to incur the obloquy of persons in high positions in consequence of the antagonistic positions they have taken. ${ }^{76}$ This was intrepid, given that the Governor; Sir William Robinson, had personally requested the second Saturday evening performance. ${ }^{77}$ Cox concluded by declaring that the AFA and the Point McLeay Mission in concert with the police had always tried to prevent Aborigines attending the Governor's Queen's birthday assemblies in Adelaide 'well knowing that moral and physical damage was the constant result'.

Despite personal and professional crisis, mission superintendent Frederick Taplin joined the controversy. ${ }^{78}$ It was not moral or physical damage that he deplored; his objections were more those of an aggrieved commercial competitor. Mission stations

73. In its 1888 Annual Report the Aborigines Friends Association approvingly noted how in NSW and Victoria 'measures have been taken for more completely controlling the aborigines; the people being to a large extent restricted in their movements' (Aborigines Friends Association Minutes Book Annual Report 1888 Mortlock Library, Adelaide).

74. Aborigines Friends Association 30 June 1885 Yearly Report Mortlock Library, Adelaide.

75. Register, 30 May 1885.

76. Register, 1 June 1885.

77. Letter from John Creswell, Secretary, South Australia Cricketing Association, to Thomas Worsnop, Adelaide Town Clerk, 28 May 1885, Adelaide Council Archives TCD Accn. 2530, Box 154, Loc.128/0/3, No. 1351. The Governor had missed the Friday night performance because he was already committed to attending the Vice-Regal Command Night, at Gamer's Theatre, as part of Her Majesty's Birthday Celebrations. Register 29 May 1885.

78. Taplin had resigned as Superintendent of Point McLeay along with head teacher J. A. Ophel and his daughter on 4 May 1885. The withdrawal of his resignation was accepted on 18 May 1885. The AFA Committee had responded to the resignations by the appointment of a subcommittee 'to examine the whole circumstances of the institution with a view to reducing the expenditure.' (Aborigines Friends Association Committee Minutes 4/5/1885). On 28 May 1885 the AFA Committee resolved to accept a sub-committee recommendation that all mission purchases and sales over $£ 10$ were in future to have the prior approval of the Secretary of the Aborigines Friends Association. Notably, the current bank balance of $£ 221.2 .10$ was not much more than was earned by the Adelaide Oval corroborees two days later. 
were supported by the Government and the public, he claimed, to 'cultivate industrious habits'. This program had been more or less successful, 'but now a new danger has arisen.... bands of aborigines trooping through the country towns earning money by means of a beastly exhibition.' In this they were aided by 'a well-meaning Government' providing 'a special free train' to take people to Adelaide, as well as by a 'sharp business man'. 79

Creswell was not deterred. Immediately following the successful Aborigines vs Wanderers football matches, he wrote to the AFA seeking their support for another match. The Association replied that they 'could not in any way give their consent', specifically linking their refusal to 'the recent congregation of natives for the corroboree'. ${ }^{80}$

Taplin's problems with the 'persons in high positions' and their fancy for the 'gala corroboree' framing were to persist. In August 1887 Taplin wrote to Protector Hamilton, refusing his request that the proposed Point McLeay Mission delegation to a Royal Geographic Society of South Australia conference in Adelaide in September be allowed to hold a corroboree. ${ }^{81}$ The corroboree, however, went ahead. Seventy-seven Aborigines from Point McLeay and Point Pearce Missions visited Adelaide, and under the auspices of the Society, held a corroboree at the Jubilee Exhibition. ${ }^{82}$

The patronage of the powerful had proved too strong for the missionaries, and by the end of the year the AFA itself was shepherding Aborigines to the Jubilee Exhibition, supervising 'the encampment at the Exhibition with the meetings and entertainments in the city'; the AFA Annual Report added 'Although we strongly disapprove of natives being permitted to frequent the centres of population, an occasional opportunity of visiting the city may prove helpful and elevating to the young people' ${ }^{83}$

It was also to 'prove helpful and elevating' to the Mission. The two corroborees performed at the Jubilee Exhibition played to packed houses with 4,500 attending the first night. ${ }^{84}$ This earned the Point McLeay Mission $£ 16$ from the Jubilee Exhibition promotors, whose chief was Sir Edwin Smith ${ }^{85}$ Further 'entertainments' provided by the Aborigines for the Adelaide public during the visit earned the Mission another $£ 5.7 .6 .^{86}$

79. Register, 3 June 1885.

80. Aborigines Friends Association Committee Minute Book, 18 June 1885, Mortlock Library, Adelaide.

81. South Australian Archives GRG 52/1/1887 No. 177, p. 268.

82. Observer 10 September 1887.

83. Aborigines Friends Association Committee Minutes Book Annual Report 30 June 1888, Mortlock Library, Adelaide. The press supported the Aborigines Friends Association's change of heart. Only a year after police intervened to prohibit a repeat of the 1885 Adelaide Oval corroboree, it was reported that 'The announcement that a number of aboriginals would perform at the Exhibition met with general favour. Adelaide people have not now many opportunities of seeing a number of natives in the city' (Register, 7 September 1887; Observer, 10 September 1887).

84. Register, 7 September 1887; Observer, 10 September 1887.

85. Aborigines Friends Association Annual Report 30 June 1888. Smith's patronage of cricket and football in South Australia has been noted above. He was vice-president of the Exhibition organising committee, and the event's personal guarantor following the withdrawal of Government support for the venture.

86. Aborigines Friends Association Committee Minutes Book Annual Report 30 June 1888, Mortlock Library, Adelaide. 
Taplin also allowed his charges to play in a South Australia Cricketing Associationorganised football match, which netted the Point McLeay Mission another $£ 2.16 .9$ profit. ${ }^{87}$ Along with the sale of souvenir basketware and woven mats, Aboriginal contributions to Point McLeay Mission income in 1887, as an outcome of their Adelaide performances, totalled $£ 25.4 .3$. This was more than the annual salary of the newlyappointed Point McLeay Mission school matron. ${ }^{88}$

The missionary fund-raising corroboree, which simultaneously harked back to the Mechanics' Institute display of corroboree as civilised concert piece, and competed with the sportsmen's corroboree as entertainment and skill exhibition, was thus implemented reluctantly and late in the century. It was a turning point in the development of 'joint venture' corroboree performance. In terms of what was being presented, it was in many ways the beginning of the staged tourist product that was to be offered to visitors at various mission stations during the early twentieth century.

Ironically, this drew largely on Aboriginal utilisation of the quasi-theatrical formats adopted by the Band of Hope, Blue Ribbon Army and similar temperance groups at their meetings. Many Point McLeay residents had become members of the Band of Hope temperance society established there in 1882 which 'provided an outlet for talent and self-expression' ${ }^{89}$ The temperance 'satire on civilisation' at the Adelaide Oval on 29 May 1885 certainly drew on this background; its performers had almost certainly attended, and possibly performed at, the special forty-fifth anniversary of the South Australian Total Abstinence League and Band of Hope Union, which ended in Adelaide on May $25 .^{90}$ On 2 June 1885, Harry Hewitt, Archie and Frank Blackmore and two others recited and sang hymns at a City Mission Hall temperance meeting; Hewitt told the audience that 'at the Point McLeay Mission fortnightly temperance gatherings took place, when songs, recitations, dialogues, \&c., were given.'

By 1895 the AFA, in contrast to its earlier attitude to corroboree performances, actively encouraged a tour of Adelaide by the Point McLeay Mission Glee Club because of its ability to raise funds for the mission. While the Glee Club periodically disbanded as its members went shearing, the Aborigines Friends Association Annual Report showed that the Club in 1900 made over $£ 209$ for the Point McLeay Mission through its concerts. ${ }^{91}$ The Glee Club's popularity was used by the AFA to boost support for its AGMs, held in the Adelaide Town Hall. In 1898, a massive exhibition of mats and baskets and other local products was added. ${ }^{92}$

87. Aborigines Friends Association Minute Book 1888 Annual Report. Mortlock Library, Adelaide.

88. Jenkin 1979 , p. 182.

89. Jenkin 1979 , p. 187

90. Register, 26 May 1885. As captain of the Aboriginal football team then playing in Adelaide, Hewitt did not miss the opportunity to advertise 'the fact early next month he would bring down twenty men to play football, all of whom were members of the Blue Ribbon Army. They then intended to hold special [temperance entertainment] meetings, for which they would prepare' (Register, 3 June 1885). This was the South Australia Cricketing Association-scheduled match of July 6 , which, as has been seen, was vetoed two weeks later by the Aborigines Friends Association.

91. Jenkin 1979 , p. 226

92. The sales success of these items, led to mat and basket weaving becoming included in the Point McLeay Mission school curriculum in 1904 (Jenkin 1979, p. 227). 
In 1908 passenger-boat owners began operating weekly tours to the Mission for summer holiday-makers at Goolwa. Some 2000 tourists visited over the summer of 1908-9, enjoying singing performances and buying mats and basketware as souvenirs. ${ }^{93}$

The apotheosis of the missionary corroboree came with Point McLeay Mission's participation in the Commercial Travellers Club Charity Fancy Dress Football Carnival at the Adelaide Oval in 1911. The annual Commercial Travellers Club carnival had become a 'a settled institution' in Adelaide, since its inception in 1907. In 1911, 40,000 were expected to attend to experience not only fancy dress football, but 'a galaxy of oddities', and people 'making asses of themselves' for charity along with the whole gamut of side-show and circus spectacle-and for the first time, a corroboree.

This event encapsulated all available framings for the tourist corroboree. It was a 'peace corroboree' in that it was specifically perceived as being 'as perfect a reproduction of their old war dances as the laws of decency and their personal ability permit', but in the context that a 'proper corroboree' cannot be seen except 'in the faraway haunts of the blacks', that is, that the truly warlike dances were no longer a part of settled South Australia. 94 The 'command performance' framing continued with the attendance of the Governor, who paraded across the Oval between a guard of honour of six hundred boy scouts. The 'gala' corroboree framing was clear in the secular, non-governmental gala nature of the event. The charity focus of the event did not disguise the fact that it was the major annual promotion for commercial travellers and their industry. Courtesy once again of the South Australia Cricketing Association, the corroboree was to be staged on the Adelaide Oval. Finally, there was the 'missionary corroboree' framing. It was reported that 'The mission was delighted to fall in with the suggestion' of a corroboree 'as the mission has been selected as one of the beneficiaries this year'.95

The joint-venture corroboree had become well and truly framed by previous framings of the corroboree. At the same time, the result of the various manoeuvrings by competing non-Aboriginal interests had relegated the corroboree to a side-show. Aborigines, always a social side-show in colonial society, now found as corroboree performers that if the the world of the side-show was to be their lot, they might as well dispense with the joint venture. Accordingly, the joint venture began to give way to independent groups as primary holders of the tourist corroboree tradition.

\section{The independents}

In 1905 Harry Hewitt, leader of the 1885 Adelaide Oval corroborees, was acclaimed for leading twenty 'local aboriginals, with the assistance of their friends from the neighbouring towns' in a corroboree at the developing tourist town of Victor Harbour. ${ }^{96}$ 'Almost the whole town turned out to witness the event' which 'lasted for about two

93. ibid.

94. Advertiser, 7 November 1911.

95. ibid.

96. In 1886 the Port Victor District Council had asked police to remove the Aboriginal camp, because of its smell, 'before the influx of visitors during the Christmas holidays' with the exception of old Poole 'who will be allowed to remain in the house purchased for him by the Council.' Poole was at that time himself a visitor attraction (South Australian Archives GRG 52/1/1886, 22 December 1886). 
hours' and 'a good collection was taken up'. The corroboree was presented as a war dance, the performers 'dancing in their fighting array with waddies and actions of a warlike character. Weird and strange white markings decorated their bodies, making them look hideous...they wore fantastic headdress, and had leaves around their ankles. ${ }^{97}$ Presaging behaviour that was to become common in future corroboree performances, it was reported that 'a visitor intends taking a photograph of the corroboree party, in all its warpaint'.

Three features of Hewitt's corroboree deserve comment. The first is that the event was independently organised, without joint-venture partnership of any sort. This style of independent organisation had continued since the first Park Lands corroborees. In Clare, in 1860, for example, about twenty Aborigines near Clare were reported to

enliven us every evening with their corrobories... Two or three times during the performance one of them carried round a hat, stating that the smallest contribution would be thankfully received. ${ }^{98}$

Corroborees in the Adelaide Park Lands were particularly likely during the months of April and May, when groups would travel into town in anticipation of the Queen's Birthday celebrations and blanket distribution-'When the moon rises early they make a diversion among themselves called "corrobbery" and to get money from the white people. ${ }^{99}$ These events were pre-planned, rather than ad hoc; Noah Shreeve, writing in 1864 , gave an account of his visit to the camp one Saturday evening. When he asked to see a corroboree that night or Sunday he was told to return on Monday, when a performance was planned. ${ }^{100}$

Shreeve had also noted that this group, educated at Point McLeay Mission, could 'read write and speak English' ${ }^{101}$ The importance of writing English was underlined by the appearance, in March 1872, of the following advertisement in the Express and Telegraph:

Wanted to give Notice that there will be a BLACKFELLOWS CORROBBOREE on the Nth Park Lands, at 8 o'clock pm THIS EVENING March 5. This is a genuine announcement. JACK FISHERMAN, GEO. BENNET. ${ }^{102}$

Reviewing the performance the next day, the Advertiser reported that:

in compliance with an advertisement in the Express, a blackfellows corroboree was held on the Nth Park Lands on Tuesday evening. Some eight men, daubed over with whitening paste, danced to the monotonous chant of four lubras. There was a large number of spectators and the blacks seemed to get a good many coppers. 103

These corroborees were organised in a milieu where 'travelling shows' of great variety were a characteristic form of entertainment in South Australia and elsewhere. In

97. Advertiser, 11 February 1905

98. Register, 13 February 1860, quoted in Noye 1986, p. 218.

99. Shreeve 1864, p. 36.

100. Shreeve 1864, pp. 38-9.

101. hid.

102. Express and Telegraph, 5 March 18722A. While the name of the former is at least suggestive, it has not been possible to ascertain whether either man or both men was or were Aboriginal.

103. Advertiser, 6 March 1872 2D. 
1883, for example, the Nardoona Minstrels, a 'burnt cork' blackface troupe, gave concerts in Mt Barker, and were applauded for their "talkey-talkey" nigger business'. ${ }^{104}$ In Melrose, in 1890, travelling Aborigines held a corroboree; one of the group advertised the fact, as other travelling showmen did, by going around the township beforehand ringing a bell. ${ }^{105}$ In 1898, in Broken Hill, 'Poolamacca' Aborigines were to be found performing corroborees at the 'Proprietary paddock' for the local population, 'with the view of raising funds to provide them with means of combating the coming winter' ${ }^{106}$ The same year at Beltana, in the Flinders Ranges, 'nearly all the town turned out to see a corrobboree held by the blacks ... [the] spectators sat on almost precipitous rocks that rose above the flat that the natives had chosen.. ${ }^{107}$ In 1904 in Wirrabara over a number of days thirty to forty Aborigines entertained 'A large number of spectators... with their corroborees and exhibitions of boomerang-throwing [at which] Some of them are very expert, particularly Old Black Warrior who wears an old grey belltopper, bearing the words, "King Warrior"". 108

In 1896 the Bulletin's theatre gossip column reported that:

An aboriginal theatrical co. has started operations in Queensland. Some 53 blacks of both sexes are running the show on approved 'white lines', commingled with the 'corroboree' element. The 'co.' pitched its tent at Cooperoo last week, and the whole district turned out to witness the first performance. The 'manager' was a stalwart nig. who announced that the admission was a silver coin: 'children one fellow penny'. 109

This theatre company may have been the group responsible for the most successful side-show of the 1896 Tenterfield Show held that month, a corroboree in 'full war paint' held in the evening under electric light. ${ }^{110}$ Hewitt's 1905 corroboree therefore was typi-

104. Mount Barker Courier, 3 August 1883.

105. Obseroer, 6 April 1895.

106. Observer, 7 May 1898.

107. Observer, 3 November 1898. This corroboree was described as follows: ‘

the actors, naked from the waist, were painted with broad white bands over face, neck, arms and body. Some of them had great feather erections on their heads and wore a kind of sporran made of wool. The leader carried in each hand a Maltese cross of wood, each point having a bunch of white feathers attached, and others had the same shaped frame with scarlet threads wound across and across. An old man, clothed in a long coat that looked like a high priest's robe, stood in front beating two boomerangs , and chanting a low monotonous song, to whose time the naked feet of file warriors stamped and beat in unison. The women kept the fire going, and one joined the "high priest's chant and beating her hands.' Cawthorne in his description of the Kure dance termed the the wool-wound cross a 'palyertatta'.

(This is also referred to by Tindale \& Lindsay as a 'paljatata' or 'thread-cross ornament'). It is featured in Angas's watercolours of Kuri dance performers (Tindale \& Lindsay 1963, facing p. 96) and in W. A. Cawthome's drawing in the Illustrated Australian News of the Ngadjuri's Kure dance that was to be performed for the Duke of Edinburgh in SA in 1867. G. W. Stacey's and A. Horrocks's memoirs of Clare Valley corroborees, as quoted in Noye 1986, contain similar descriptions.

108. Advertiser, 23 April 1904

109. Bulletin, 14 March 1896. This was reported in the regular column 'At Poverty Point'.

110. Brisbane Courier, 16 March 1896. Holding of a 'Blacks Corroboree' was part of the Show's prepublicity. Brisbane Courier, 3 March 1896 and 4 March 1896. 
cal of a continuing tradition of independently organised 'strolling player' performances.

The second characteristic of Hewitt's corroboree was its seaside location. Aborigines at the end of the nineteenth century clearly used tourist corroborees to support their annual return to traditional summer campsites. Thus in the summer of 1897 Aborigines, returning to their traditional camp sites at Glenelg, began once again to perform corroborees for Adelaide residents. ${ }^{111}$ In January 1898, it was reported that 'cartloads' of Aborigines had arrived and held a corroboree on a Friday evening. Though no 'admission price' was mentioned, this enterprise clearly had a commercial aspect, being performed in the height of summer in the tourist and holiday season, when the premier beach suburb was in full carnival mode.

By this time, professional Aboriginal corroboree dancers were more alert to 'introducing too much of the European element', and the demand for an 'authentic' presentation. Thus, in this performance, fifteen performers 'stripped to the waist' performed 'a tribal war dance. The body of each native was gloriously painted; plumes bedecked the head, while a plentiful display of leaves and feathers encompassed knees and hips of some performers'. They danced 'with zest' and 'the warlike attitudes at times assumed were quite in keeping with the fierce and fiery eye characteristic of the blacks of Australia in moments of rage. 112

That same summer it was reported that residents at Grange, a little further north on the Adelaide coast:

were treated to a real aboriginal corroboree last night. 18 full-blooded blacks took part in an entertainment, which was held on the beach and all the natives were in their proper war-paint. ${ }^{113}$

In April 1905, it was reported that 'over a dozen' Aborigines of the 'Tury tribe' from $\mathrm{Mr}$ W. H. Bowman's station gave a corroboree at Colley's Reserve, Glenelg.

The event proved a great attraction and hundreds of people gathered around the blacks who were in their 'warpaint'...the spectators became so interested that, notwithstanding the efforts of Sir Jenkin Coles, who was in the ring, the space became so circumscribed that the blacks could not continue the entertainment. ${ }^{114}$

Such corroborees continued along Adelaide beaches for at least a decade, displaying varying degrees of spontaneity, planning and organisation. In 1907 Aborigines, who had been observed 'gathering for some time at Henley Beach from different directions, making camp in the dunes near the seashore...(this week introduced) several corroborees into the programme and they proved interesting and remunerative.' Grange's summer holiday-makers also received a visit from these performers. ${ }^{115}$

111. Advertiser, 13 October 1897.

112. Advertiser, 31 January 1898.

113. Advertiser, 10 March 1898. This account was disputed by 'Wopshot' who claimed that the corroboree was performed reluctantly, at the instigation of well-known resident J. T. McLean (Advertiser, 12 March 1898).

114. Advertiser, 3 April 1905. From 1890 to 1911, Sir Jenkin Coles was Speaker of the South Australian Parliament.

115. Register, 18 May 1907. 
The third characteristic of Hewitt's corroboree worth noting is its emphasis on 'war dance' and 'actions of a warlike character'. This emphasis was a response to a new framing of the tourist corroboree. In 1887, the year of the Jubilee Exhibition 'sham battle' corroboree, the Illustrated Australian News had featured an article entitled 'War Dance of the Natives'. It reported that:

The Australian Aboriginals are rapidly disappearing... The natives which remain uncivilised are only found in the back blocks of the Northern Territory and Western Australia; but they are miserable and treacherous at best. Occasionally a tribe may be found... willing for a consideration to interest strangers by an exhibition of a war dance. ${ }^{116}$

The 1887 Jubilee Exhibition 'sham battle', like the 'old war dances' of the 1911 Commercial Travellers corroboree, was not a re-enactment of the past, but an evocation of the present, as representation, especially, of the Northern Territory frontier. Re-awakening and sustaining public patronage of corroborees in Adelaide were the dispatches from the Spencer and Gillen expedition to Central Australia. Accounts of corroborees were often featured in their press reports. ${ }^{117}$

The Northern Territory frontier had become a new framing of the corroboree reproduced by the Aboriginal seaside entertainers and strolling players at the end of the century. At the same time, it had become a new location for the tourist corroboree, as Northern Territory Aborigines began to exploit their symbolic capital in the new settlement context.

\section{Conclusion}

In Adelaide within the first ten years of settlement, the town's Aboriginal population had begun meeting a growing demand from newly-arrived Europeans for 'corroborees'. The settlers' valuing of such symbolic goods was, for Aborigines, a reinforcement of the value and status of their traditional cultural practices and beliefs. It was, therefore, also a threat to those Church and State authorities endeavouring to have them repudiate such practices and beliefs and replace them with their own.

Making these authorities' task more difficult was the fact that settler small business, in particular publicans and others in the outdoor entertainment industry, seized the opportunity early to take a position in the market as promoters and impresarios. They arranged or booked venues, assisted with staging, props and effects, and in advertising and promotion of the product. For many settlers and visitors in Adelaide (and other capitals) the corroboree became a 'must-see' tourist attraction, and grew to become metonymic for Aboriginal culture.

The 'tourism corroboree', along with other aspects of Aboriginal cultural tourism, is located within a moving colonial political economy of the sign. In South Australia in the nineteenth century it absorbed influences from Victoria and moved northward into the Northern Territory with the moving frontier, where it continues to flourish. In this movement signs of the quest for equality, independence and identity abound, by both colonised performer and colonising audience, and are negotiated in complex attempts

116. Illustrated Australian News, 20 August 1887, pp. 148-154.

117. Reproduced from the Melbourne Age in the Advertiser. An example is 'The Blacks of The Interior' entirely about corroborees, written by Spencer himself, Advertiser, 10 August 1901. 
at satisfying competing and complementary demands within an overarching framework of a growing asymmetry of power relations.

Elsewhere, the implementation of policies of social isolation, the alienation of traditional lands, and the removal of children from their parents were to have long-lasting impacts. In the immediate instance, a corroboree performance was an ideally portable, and seemingly inalienable product, requiring no access to traditional lands. However, in the long term, the breaking of the nexus of the physical and the symbolic, in which the performance of corroborees were embedded, was to have a transforming effect. Formerly the social reproduction of cultural capital had required access to land for the performance of ritual, and the instruction of children. It is no wonder that modern day Aboriginal cultural tourism has arisen in the context of the restoration of this nexus, of land rights and Link-Up. For some, however, the enduring consequences of this double dislocation from land and from children, was also to demand a reconstruction of ethnicity, giving rise to an emergent authenticity in their touristic products.

\section{References}

Altman, J. 1988, Aborigines, Tourism, and Development: The Northern Territory Experience, Darwin.

Appleyard, Ron, Fargher, Barbara \& Radford, Ron 1986, S. T. Gill. the South Australian years, 1839-1852, Adelaide.

Berndt, Ronald M. \& Berndt, Catherine H. 1985, The World of the First Australians, 2nd edn, Sydney.

Bruce, Candice \& Callaway, Anita 1991, 'Dancing in the dark: Black Corroboree or White Spectacle?' Australian Journal of Art vol ix, pp. 78-104.

Cannon, Michael 1990, Who killed the Koories?, Melbourne.

Clark, Manning 1968, A History of Australia, Melbourne.

Gunson, N. (ed.) 1974, Australian Reminiscences and Papers of L. E.Threlkeld, Missionary to the Aborigines, 1824-1859, Canberra.

Hampton, Ken \& Mattingley, Christobel, 1988, Survival in Our Own Land: 'Aboriginal' experience in 'South Australia' since 1836, Adelaide.

Jenkin, Graeme 1979, Conquest of the Ngarrendjeri, Adelaide.

McCannell, Dean 1992, Empty Meeting Grounds: the Tourist Papers, New York.

McNeil, Kent 1989, Common Law Aboriginal Title, Oxford.

Macquarie, Lachlan, 1956, Journal of his Tours in NSW and Van Diemen's Land 1810-1822, Sydney.

Manning, Daniel 1976, Kensington and Norwood Sketchbook, Adelaide.

Mitchell, Sir Thomas 1834, Three Expeditions into Eastern Australia, 2 vols, London.

Noye, Robert J. Clare: a district history, Adelaide, 1975.

Reece, R. H. W., 1967, 'Feasts and Blankets: the history of some early attempts to establish relations with the Aborigines of NSW, 1814-1846', Archaeology and Physical Anthropology in Oceania, vol. 2, no. 3, pp 190-206.

St. Leon, Mark 1993, The Wizard of the Wire: the story of Con Colleano, Canberra.

Shreeve, Noah 1864, A Short History of South Australia, London. 
Smith, Russell, [1973], 1850: a very good year in the colony of South Australia: selected items of historical interest, Sydney.

Stephens, Edward 1889, 'The Aborigines of Australia', Journal and Proceedings of the Royal Society of New South Wales, vol. 23, pp. 476-503.

Taplin, G., 1979, 'The Narrinyeri' in The Native Tribes of South Australia, ed. J. D. Woods, Adelaide.

Therry, Roger 1863, Reminiscences of Thirty Years' Residence in New South Wales and Victoria, London.

Tindale, Norman B. \& Lindsay, H. A. 1963, Aboriginal Australians, Brisbane. 